COMPTES RENDUS

\title{
SCIENCES VARIA \\ VULGARISATION SCIENTIFIQUE
}

Jean d'Alembert, savant et philosophe : portrait à plusieurs voix. Actes du Colloque organisé par le Centre international de synthèse-Fondation "Pour la Science ", Paris, 15-18 juin 1983. Eds Monique Emery, Pierre Monzani. Paris, Éd. des Archives contemporaines, 1989. 13,5 x 21,508 p., index.

Les Actes de ce colloque contiennent vingt-sept articles aussi divers que l'activité du philosophe et du savant que fut Jean Le Rond, dit d'Alembert. Préparé et publié avec soin, le livre se termine par un précieux index des noms propres auquel il aurait été utile de joindre les titres des œuvres de d'Alembert, utilisées par les différents auteurs de communications.

Essayer de présenter d'Alembert dans la littérature des Lumières (R. Mortier, p. 17-39) ou le juger en tant qu'homme de science (Th. Hankins, p. 187-205), en présentant les difficultés de ces deux positions était une démarche qui s'imposait pour la célébration du bicentenaire de la mort de celui qui fut à la fois attachégéomètre puis pensionnaire titulaire à l'Académie des sciences et secrétaire perpétuel de l'Académie française. J. Dhombres étudie quelques-unes de ses « attitudes ", mettant en évidence "son souci profond des fins de l'institution" (p. 167-185).

Les préoccupations du biographe de d'Alembert, J. Pappas, le conduisent à exposer les «problèmes ", inévitables dans ce genre difficile (p. 85-109). Le document qui suit son exposé, un pamphlet contre d'Alembert, illustre bien les difficultés de dosage délicat dans la prise en compte - on ne peut pas la passer sous silence quand elle existe - de cette littérature de ragots. La « vérité biographique " a d'ailleurs été abordée par d'Alembert lui-même, ainsi que le rappelle W. Voisé (p. 111-118). Il l'a mise en pratique d'une certaine manière dans ses Éloges. Le problème n'est pas abordé dans son ensemble, mais D. Essar l'envisage dans les deux cas de Bossuet et de Fénelon, mettant en évidence « la caricature dans le récit historique " (p. 55-84). C'est à un détail biographique, la visite de d'Alembert à Genève en août 1756, que l'on doit une des plus grandes batailles du siècle, soulevée par l'article "Genève ", paru dans le tome VII de l'Encyclopédie, comme on le sait. J.-D. Candaux revient sur ce sujet en tant que Genevois, en analysant les circonstances de l'enquête de l'encyclopédiste (p. 119134). Deux points de détail encore : les rapports de d'Alembert avec Montes-

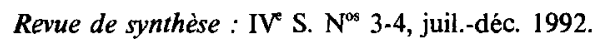


quieu sont examinés par R. Shackleton (p. 41-53) et ceux de d'Alembert avec les savants de Genève par P. Speziali (p. 461-474).

La nature de la philosophie de d'Alembert intéresse plusieurs communications. "Quel philosophe?" se demande Y. Belaval qui continue ici son «esquisse", commencée dans le numéro spécial de Dix-Huitième siècle, 16, 1984 (dans lequel plusieurs articles complètent les aspects abordés dans le volume que nous présentons ici). Sa philosophie est « une philosophie à principes mais sans fondements ". Cette affirmation mériterait une discussion qui pourrait nous entraîner sur la place que tient le dix-huitième siècle français chez les historiens de la philosophie. P. Casini, qui étudie l'« économie des principes » et le refus de la métaphysique conclut que "le mérite de d'Alembert comme épistémologue est celui de n'avoir jamais cédé à l'esprit de système " (p. 135-152). Il étudie aussi le glissement du mathématicien vers le « scepticime ", vocable qui revient souvent à propos de d'Alembert (on peut se demander si le portrait que fait Diderot dans $L e$ Rêve de d'Alembert n'influence pas notre jugement). La position épistémologique de d'Alembert est aussi au centre de l'étude de M. Paty, orientée sur les rapports des mathématiques et de la physique, et singulièrement de la physique théorique et de la dynamique (p. 232-260). L'hydrodynamique est alors fondée sur les mêmes principes que la dynamique, branche de la mécanique rangée dans les mathématiques "mixtes" (revoir le "Système figuré des connaissances humaines " du Discours préliminaire).

C'est aussi dans cette branche des mathématiques que se place l'« Art de conjecturer ", autrement dit le calcul des probabilités et c'est à ma connaissance la première étude fouillée des "doutes de d'Alembert " en cette matière que présente B. Bru (p. 279-292). L'auteur part de certains articles de l'Encyclopédie ( "Croix ou pile ", " Gageure ») pour analyser la discussion sur la nature des cas également possibles quand on lance une pièce deux fois (d'Alembert en trouvait trois, ses contemporains quatre) et celle du problème dit de St-Petersbourg qui mène à un enjeu infini. B. Bru montre que ces « doutes » (sur lesquels d'Alembert revient en 1765 dans ses Mélanges..., en 1768 dans ses Opuscules et dans ses derniers écrits) ont reçu une réponse dans la théorie bayésienne que présentent Condorcet et Laplace.

D'Alembert est aussi un mathématicien «pur» (ainsi le veut la terminologie) et, dans ce domaine, il était considéré, par ses contemporains, l'égal d'Euler, comme le rappelle $A$. Youschkevitch dans un exposé d'ensemble sur l'analyse mathématique, qui insiste sur l'importance de ses découvertes (p. 315-332). C'est à l'une de ces découvertes, la théorie des équations différentielles aux dérivées partielles, que s'attache S. Demidov (p. 333-350). Dans un mémoire intitulé Réflexions sur la cause générale des vents qui remporta le prix de l'Académie de Berlin en 1746 (dont A. Kleinert nous expose les circonstances, p. 415-431), d'Alembert expose ce qui devait devenir une théorie puissante qui suffirait «pour que son nom soit immortalisé dans l'histoire des mathématiques » (p. 347). Par l'évocation de la démonstration du "théorème fondamental de l'algèbre", Ch. Houzel (p. 351-359) discute l'existence des racines d'un polynôme, et en vient à l'étude des nombres imaginaires. Ce statut des nombres imaginaires chez d'Alembert ( $i$ est une notation qui n'apparaît qu'en 1777 chez Euler) est examiné plus en détail par J.-L. Verley (p. 361-375). 
Concernant les «définitions géométriques", J. T. Desanti nous conduit à regarder de plus près la «simplicité » de l'objet mathématique (p. 225-232) : " seules les idées composées peuvent être définies et exigent de l'être ", les idées simples ne pouvant et ne devant pas être définies d'après d'Alembert (" espace ", " temps ", " point ", par exemple). On peut rapprocher ce souci de la définition qui, en mathématiques, consiste en général à remplacer une ou plusieurs phrases par un nom, de l'étude de S. Auroux qui se penche sur la philosophie du langage de d'Alembert et souligne l'importance pour lui de la communicabilité (p. 214).

Personne n'a été tenté d'étudier d'Alembert polémiste et, pourtant, ses articles dans les périodiques du temps, ont presque toujours pour prétexte une « dispute " pour employer un terme d'époque (avec Clairaut, avec Rameau, etc.). Plusieurs communications parlent de «querelles » : celle sur l'inoculation avec $\mathrm{H}$. Le Bras qui examine le mémoire de 1760 (J.-N. Biraben présente une vue plus générale sur ce problème au Xvirie siècle, p. 303-313); celle des forces vives qui est l'occasion pour P. Costabel d'un " examen critique » de la position de d'Alembert dans les deux éditions du Traité de dynamique (p. 377-393). S'il n'y a pas querelle à proprement parler, il y a bien un peu de polémique dans la façon dont d'Alembert traite du problème des trois corps en rivalisant avec Clairaut et Euler sur le sujet (article de R. Taton, p. 395-414).

Autour du canal de Picardie il s'agit d'une « affaire " à laquelle d'Alembert fut mêlé avec Bossut et Condorcet: affaire compliquée qu'expose P. Redondi, où l'enjeu était de passer de l'hydrodynamique spéculative aux expériences hydrauliques réussies, sans parler des conflits d'intérêts (p. 433-460).

Deux communications ont abordé des domaines bien différents, l'une la chimie dont d'Alembert s'est fort peu préoccupé (J.-C. Guédon, p. 261-277), l'autre la musique à laquelle il a consacré plusieurs écrits. M.-E. Duchez examine comment il a diffusé la théorie harmonique de Rameau et comment il l'a appauvrie au point de vue musical: l'auteur parle même de désastre (p. 490), débat sans fin. Noublions pas que Rameau après des «calculs » longs et pénibles parachevait l'accord du clavecin à l'oreille!

En conclusion, ce volume, sans épuiser tous les centres d'intérêt du philosophe (au sens du xvili ${ }^{e}$ siècle), dont les contributions aux sept premiers volumes de l'Encyclopédie donnent une idée, permet de progresser dans la connaissance d'une œuvre qui attend d'être publiée pour en exposer toutes les richesses. Le projet était déjà envisagé en 1983. J. Dieudonné appelait de ses vœux « cette édition exhaustive et irréprochable ", nous disait J. Roger dans son avant-propos. La question est encore d'actualité : une nouvelle équipe s'est formée, qui espère mener à bien ce travail. 
Michel Delon, L'Idée d'Énergie au tournant des Lumières (1770-1820). Paris, Presses universitaires de France, 1988. $14 \times 21,528$ p. (« Littératures modernes $")$.

Après deux livres classiques pour les dix-huitiémistes, L'Idée de Nature (J. Erhard) et L'Idée de Bonheur (R. Mauzi), M. Delon nous propose une Idée d'Énergie. Selon l'auteur, après l'offensive menée par Michei Foucault contre l'histoire des idées, qui fut en son temps une période de «plaisir de la polémique ", il faudrait en revenir à une histoire des idées rénovée. Pour cela, il convient de prendre en compte la diversité littéraire - traités théoriques, textes de théâtre, pièces de vers, romans -, dont l'unité n'est plus assurée par un auteur, comme dans l'ancienne histoire littéraire, mais par une « situation historique ». M. Delon confesse sa dette envers Jean Fabre qui, dans Lumières et Romantisme, avait défini une catégorie fondamentale pour l'étude du xvir ${ }^{e}$ siècle - celle d'énergie - et un objet d'étude : l'articulation de deux époques. L'auteur répond à «l'appel " de Jean Fabre et s'attelle au travail : le mot et la notion d'énergie doivent être suivis dans « leur diversité et leur évolution». Pour mener à bien cette tâche, il convient, selon M. Delon, d'explorer la "multiplicité " des acceptions de cette notion, en même temps que son "ambiguïté " et son « archaïsme».

Deux parties dans ce livre bien structuré : «Les Mots et le Monde ", " Le Moi ». Dans la première, un grand nombre de domaines sont abordés qui recouvrent - en un propos encyclopédique - des parties essentielles du savoir. L'auteur étudie chaque domaine du point de vue de la notion d'énergie. Après avoir fait l'histoire du mot (d'Aristote au classicisme), il aborde la question de l'énergie dans la langue et expose clairement les diverses positions des théoriciens du xvıı ${ }^{e}$ siècle au sujet du style (Marmontel, Condillac, Diderot) en s'attardant sur les conceptions de Court de Gébelin et des Idéologues. L'énergie dans les Beaux-Arts fait l'objet d'un chapitre où l'auteur montre entre autres que l'œuvre d'art, à la suite des théories leibniziennes développées dans les milieux de l'Académie de Berlin, possède un double statut : elle est à la fois révélatrice d'énergie et énergie elle-même. Ensuite, la littérature requiert toute l'attention de M. Delon. Après l'abandon progressif des théories classiques, il avance que l'idée d'énergie devient un critère du jugement littéraire, en même temps que l'on abandonne la poésie au profit de la prose. Suit un chapitre intitulé « Énergie ou inertie de la matière " dans lequel les théories matérialistes de l'époque, toujours du point de vue de la catégorie de l'énergie, sont clairement exposées. Un sort particulier est fait au Système de la Nature (1770) et aux critiques que ce livre a suscitées, dont l'écho se poursuit jusqu'à Bonald. Les théories de Buffon, de Diderot, de Cabanis sont ensuite étudiées pour faire ressortir leur originalité dans le domaine des sciences naturelles. Au passage, M. Delon remarque que c'est à partir d'une réaction à un matérialisme outré que Bernardin de Saint-Pierre et Mme de Staël en sont venus à défendre l'idée de la participation de l'individu à l'énergie de l'ensemble de la nature : une nouvelle époque commence. Enfin, cette première partie se termine sur un très riche chapitre consacré à l'histoire. L'auteur avance que la Révolution est vécue comme un retour à la vie et à l'énergie : ce qui est aristocratique est considéré comme léthargique. Et il cite opportu- 
nément les Considérations sur la Révolution française de Mme de Staël à propos des États généraux : « Les physionomies des députés exprimaient plus d'énergie que celle du Monarque."

"Le Moi " fait l'objet de la seconde partie de l'ouvrage : l'auteur y étudie les tensions auxquelles l'individu de l'époque a été soumis. Tout d'abord, l'énergie humaine, les rapports du physique et du moral, les implications philosophiques et morales sont analysées (Diderot, Sénancour). Le sentiment de l'existence qui s'incarne en deux mouvements - refus ou recherche de l'énergie - en la personne de Rousseau et de Saint-Lambert, puis le problème de l'ouverture à autrui et au monde sont étudiés dans des chapitres distincts. L'analyse des passions est au cœur de cette seconde partie. Elles constituent "l'énergie de la nature » (Diderot) ou « le germe productif de l'esprit » (Helvétius). Plus tard, le Groupe de Coppet et Mme de Staël, Chateaubriand et surtout Mme de Genlis, en viendront à des attitudes plus mesurées à l'égard des passions. Quel meilleur exemple de volonté que Figaro? Dans son fameux monologue, M. Delon montre que, contre une naissance servile, « l'énergie peut constituer une force de mutation et de devenir historique ". Avant de terminer sur une analyse approfondie du libertin, l'auteur rend compte des mutations des modèles sociaux: dans la seconde moitié du xviri siècle, ce n'est plus l'aristocrate, mais le marchand et le savant qui passent pour des modèles d'énergie.

Ainsi, d'une façon générale, l'idée d'énergie est-elle en œuvre dans la plupart des modes d'expression et participe à ce que l'auteur désigne comme une linguistique de l'effet. C'est un appel au mouvement, à une ouverture et à une mémoire dont le Panthéon révolutionnaire assure la dimension historique.

Le livre de M. Delon est d'un style clair et accessible. Il est parfaitement documenté et rendra de grands services au chercheur. L'un de ses mérites, parmi beaucoup d'autres, est d'avoir su retrouver et pu prendre en compte, à côté de textes connus, ceux d'un grand nombre d'auteurs aujourd'hui oubliés mais qui constituent la fibre même du XVIII' siècle littéraire. C'est un plaisir que de voir citer, dans cette étude, des textes originaux et non plus forcément les textes du corpus scolaire, constamment ressassés. Tout au plus peut-on regretter l'absence d'un index et d'une bibliographie récapitulative. Mais l'auteur n'en est sans doute pas responsable quand on connaît les contraintes éditoriales. Bref, il s'agit d'un bon livre, d'une somme même, bien digne de figurer aux côtés des ouvrages de J. Erhard et de R. Mauzi.

Hervé GuÉnot.

Nicole et Jean Dhombres, Naissance d'un nouveau pouvoir : sciences et savants en France, 1793-1824. Paris, Payot, 1989. $15 \times 23,938$ p., index (« Bibliothèque historique Payot ").

When Charles Babbage wrote his Reflections on the Decline of Science in England in 1830, he used a rather breathless admiration of France to bring out 
what he saw as the failings of British science. In some very obvious senses, Babbage was right. Over the previous forty years, France had leaped ahead of her rivals in the provision of state-funded posts and scientific and technical education. And, as a result, French savants enjoyed a security and level of public support that far surpassed anything that was available to the " gentlemen " of British science.

But, for all its superficial plausibility, Babbage's analysis was misleading. For, quite deliberately, the Reflections ignored the virtues of the traditions of self-help that had reaped far richer rewards than he cared to admit in France as well as in Britain. A reader of the Reflections would be left unaware of the sources of patronage and other means of support that had been realized in chemistry by John Dalton, Humphry Davy, and Michael Faraday and in geology by William Buckland, Adam Sedgwick, and Charles Lyell. Similarly, that same reader would be told nothing of the role of personal enterprise in the fashioning of some of the most glittering scientific careers in France between the 1790s and 1830. Modern studies of the determined advancement of such figures as Laplace, Berthollet, and Cuvier show how crucial that role was and hence how inadequate any study of institutions and patronage must be unless it also treats the manœuvrings of those who exploited the opportunities on offer.

Such considerations make the writing of the institutional history of French science in the golden age covered by Nicole and Jean Dhombres a hazardous business. But Naissance d'un nouveau pouvoir rises impressively to the challenge. Essentially, the book is a study of the emergence of the state of affairs that Babbage so envied. It traces the birth of a self-conscious scientific community in an age when French science and scientists were drawn, whether they wished it or not, into an unprecedented degree of proximity to the state. The new closeness was forced upon them not by the events of 1789 , which left the "Old Régime " of French science largely untouched, but by the years of Jacobin rule and, in particular, by the closure of the academies in 1793. As a result, the "Republic of Science " was obliged, quite brutally, to rethink its relations with the world of political power. Some, like Lacépède, prevaricated, tremulously retiring to solitary study ; others, like Lazare Carnot, were ready, even eager, to be mobilized. But no savant could imagine that the life of science could go on unchanged : it did not require the beheading of Bailly and Lavoisier or the suicide of Condorcet to demonstrate that there was no going back. Some historians have been tempted to regard the creation of the First Class of the Institut de France in 1795 as a remodelling of the defunct Académie des sciences, but contemporaries were in no doubt that a new age had dawned. To pursue my reflexions on Babbage, it was not an age in which science would be the object of indiscriminate liberality but one in which there were new opportunities to be exploited.

It is a central plank in the argument of this book that savants moved with alacrity into and up the new structures, especially in education and the technical services. They paid ready lip-service to the pompous assertions of the diverse utilities of science, ranging from its value in purifying the mind (an argument especially favoured by Lacroix, in the tradition of Condorcet) to its (equally ill-defined) contribution to the war effort... But as they did so, and in certain respects lost their autonomy, they acquired an esprit de corps and a power as citoyens-savants 
which they had never possessed as the largely individualistic académiciens of the Ancien Régime. Especially after the Egyptian Campaign, where the notion of men of science as the hérauts du progrès was first put to the test, in what Nicole and Jean Dhombres illuminatingly analyse as a social "laboratory ", they had a quite new sense of their common interests and value. By the turn of the century, in an episode to which the authors attach great importance, they were ready to demonstrate their sense of community in a determined and eventually successful campaign of support for the naturalist Dolomieu, imprisoned amid the confusion of war for twenty-one months in southern Italy.

Much of this book is devoted, inevitably and properly, to the years of Napoleonic rule, in which the first generation of beneficiaries of the new departures in state patronage (essentially the generation of Laplace) tightened their grip on the burgeoning world of scientific career-making by placing younger men who were in varying degrees their protégés into key positions in the educational system. Here, the description is dense, precise, and fascinating. The entrepreneurial talents of mathematicians and physical scientists emerge very clearly (more so, it must be said, than those of the life scientists and medical community), as does the gradual accommodation of the prized ideals of independence and intellectual freedom to the realities of a Kulturpolitik directed to the very different goals of efficiency and national aggrandizement. This is consistently important and often novel material.

My own sense is that the thesis advanced in this book could be quite convincingly argued through evidence drawn exclusively from the revolutionary and Napoleonic periods. In extending the discussion into the Restoration, the authors confirm that the sense of community that had been achieved by 1815 was preserved under Louis XVIII, whom they see as simply indifferent towards science. But, by ending with the death of Louis in 1824, they stop well short of the phase of professionalization which, for my money, did not begin before the 1830 s, when the belated insistence on formal qualifications (notably the doctorate) and the emergence of conspicuously more regular career-patterns set French science on yet another new course. The authors' occasional use of the concept of "profession" whith regard to the period treated in Naissance d'un nouveau pouvoir left me uncertain of the analytical value that they attached to it: the notion of " community ", itself an exceedingly difficult one, seemed more surely handled and a more useful analytical tool.

All told, this is an important book, equally remarkable for its erudition and range and for a thesis that contributes notably to making sense of four decades of remarkable creativity in science. The treatment is based on an engagement of unprecedented thoroughness with the primary sources, and hence on foundations that will ensure it a long life in the literature on the subject. Some immediate consumers may be disappointed by the rather cursory handling of the abundant existing secondary literature : certainly, a more direct confrontation with rival interpretations might have brought out even more clearly the historiographical novelties in the book. But, even if in this respect Naissance d'un nouveau pouvoir may not always do full justice to its own quality, it remains an outstanding contribution to the work of analysing French science in and just after the Revolution, and a worthy reminder 
of the scholarly activity - in print, colloquia, and museum displays - that marked the celebration of the Bicentenary.

Robert Fox.

La Science pour tous. Sur la vulgarisation scientifique en France de 1850 à 1914. Dirigé par Bruno Beguet. Paris, Bibliothèque du Conservatoire national des arts et métiers, $1990.20 \times 26,168$ p. , ill.

En 1974 paraissait Le Partage du savoir. Science, culture, vulgarisation de Philippe Roqueplo. Cette enquête réflexive et critique sur la fonction culturelle, idéologique, voire aliénante, de toutes les mises en spectacle de la science dans l'espace social, insistait sur l'ambiguïté d'une entreprise qui, dans les formes mêmes de sa popularisation, marquait la distance et la séparation des publics visés. Cette ambiguité est peut-être constitutive du genre moderne de la vulgarisation, tel qu'il apparaît en France après 1850. L'ouvrage dirigé par Bruno Béguet l'atteste clairement. C'est pourquoi les visées purement historiographiques des études rassemblées dans $\mathrm{La}$ Science pour tous ne doivent pas masquer absolument l'arrière-plan contemporain. Selon le directeur du Conservatoire national des arts et métiers, Raymond Saint-Paul, préfaçant l'ouvrage, l'écart va croissant entre le petit nombre des initiés au progrès des sciences et «la masse de ceux qui sont dans l'incapacité de comprendre cette évolution et d'y adapter leurs comportements ". Moins espoir que devoir pour le moderne, la vulgarisation est rappelée à ses tâches didactiques, non sans troubles analogies : « la vulgarisation scientifique est au monde moderne ce que la Vulgate a été, au xvie siècle, pour la diffusion de la Bible $»$ !

Toutefois, ainsi piégée entre la déconstruction polémique et l'apologie (l'apologétique ?), la popularisation des savoirs spécialisés gagne en complexité sous l'éclairage des historiens. Leurs analyses ont donné à ce problème ses titres de diversité. Elles démontrent ici qu'à travers la littérature, la presse de spécialité, les expositions universelles ostentatoires ou les exhibitions spectaculaires, la science est, dès le $\mathrm{XIX}^{\ell}$ siècle, installée " au plan des mythes ". Elle participe d'un imaginaire collectif peu respectueux du projet positiviste d'émancipation des esprits qui pourtant anime ses vulgarisateurs. Au siècle passé, la «fée électricité ", ou les expériences brillantes et détonnantes réalisées durant les conférences mondaines du Second Empire, proposeront un "merveilleux de substitution" qui ne le cédera en rien aux miracles de la Création racontés aux enfants. $\grave{A}$ un stade ultime de popularisation, la science a pu devenir « l'adjuvant du spectacle forain, à peine un prétexte ".

Face aux manifestations diverses de ce projet pédagogique, peut-on parler réellement d'un genre ? Si le livre de vulgarisation n'a « jamais existé en tant que tel », il reste pourtant que, dès les années 1850 , un certain nombre d'indices portant sur le style de l'écrit vulgarisant, sa publication en livraisons bon marché, les procédés particuliers de l'appropriation à un lectorat ciblé (réécriture, compilation, plagiat, 
reprise des illustrations), son collège d'auteurs, qui acquièrent rapidement le monopole de la diffusion, semblent fonder «l'unité d'un genre ». Néanmoins ce genre n'est pas donné à l'historien, il doit être partiellement construit. Par ailleurs, la perspective chronologique et sociologique choisie par les contributeurs Catherine Bénédic, Florence Colin, Patrick Le Bœuf, Florence Carneiro, Brigitte Rozet et Dominique Diguet - montre clairement le devenir changeant de ses supports, de ses ambitions, de ses messages. Même s'il est la référence durable de l'entreprise de vulgarisation, le livre ne la résume pas toute. Les jouets, le " théâtre scientifique ", les cours publics, les feuilletons de presse, le roman "scientifique ", les "leçons de choses " de l'école républicaine, les établissements comme le C.N.A.M. ou les galeries du Muséum d'histoire naturelle, en constituent autant de relais, de formes datées. Le concept de la diffusion des savoirs scientifiques et techniques a donc évolué au rythme des moyens de communication accessibles, mais également en fonction des mutations de l'imaginaire social de la science, de ses idéaux et de ses idéologies.

À la différence des premiers auteurs caractérisés a posteriori comme « vulgarisateurs", tels Fontenelle, Buffon ou Bernardin de Saint-Pierre dont le propos est assurément dirigé vers un public limité et mondain, la vulgarisation de la seconde moitié du $\mathrm{XIX}^{\mathrm{c}}$ siècle se caractérise par un ensemble de traits différentiels, qui assurent à la fois sa relative cohérence et sa limite temporelle.

1. Son succès accompagne la professionnalisation croissante d'une communauté scientifique incarnée dans des institutions spécialisées. Savant occasionnel, le vulgarisateur sera à son tour défini comme un professionnel de la médiation, un savant généraliste mais indépendant.

2. Une série de ruptures marque les formes nationales de la popularisation : ouverture vers un large public, ni strictement mondain, ni délibérément juvénile, même si le livre pour enfants reste un enjeu éditorial important; abandon des finalités utilitaristes, qui demeurent courantes à la même époque dans l'Angleterre victorienne. La vulgarisation encourage la réception passive ou ludique plus que l'activité d'amateur ou la culture scientifique alternative.

3. Conviction de l'utilité de la science. La vulgarisation est perçue comme un apostolat, elle est censée combattre les préjugés irrationnels du peuple et hâter le progrès social par la science, par sa diffusion. Son propos est aussi de susciter des vocations, d'instruire en amusant, d'ouvrir " une école pour la foule ", de moraliser les classes dangereuses.

4. À l'exception de l'idéologie progressiste, elle vise la plus grande audience sans généralement se mettre au service explicite d'une cause partisane, politique ou métaphysique. Le vulgarisateur se pense du " juste milieu ", en dépit des obédiences diverses de certains d'entre eux, conservateur comme Louis Figuier, républicain comme Camille Flammarion, socialiste comme Victor Meunier ou catholique comme l'abbé Moigno, le rédacteur de la revue Cosmos.

La Science pour tous est un ouvrage de synthèse, à la croisée de l'histoire culturelle et de l'histoire des sciences. Outre des analyses techniques et suggestives sur l'univers social de la vulgarisation scientifique avant 1914, il propose un « dictionnaire des vulgarisateurs », un répertoire fort nécessaire des revues de spécialité créées entre 1850 et 1914 et une liste des collections de vulgarisation disponibles dans ces dates. Au-delà des études de cas, c'est un ouvrage de référence, capable 
de refléter, dans une perspective de plus longue durée, l'écueil de la vulgarisation, ses raccourcis saisissants, ses demi-vérités et ses vraies erreurs. La vulgarisation manifeste l'écart qu'elle est censée combler. Depuis le milieu du XIX siècle, absents de la production des savoirs comme des décisions politiques qui les concernent, les consommateurs passifs d'un discours non contrôlable et unilatéral sont appelés à manifester leur " foi en la science ", à donner au moins leur adhésion à une représentation valorisée du monde de la recherche. « Le scientisme ambiant, note B. Béguet à propos des années 1850-1860, favorise une entreprise vulgarisatrice qui le renforce à son tour, en un mouvement circulaire." $\grave{A}$ un siècle de distance, rien n'indique que la vulgarisation, donnée pour « discours-de-la-réalité-elle-même ", ait renoncé à véhiculer tous les mythes de la scientificité, de l'héroïsation du savant jusqu'à la légitimation explicite de sa puissance d'expertise.

Claude Blanckaert.

Daniel RaIChVARG, Jean JACQUeS, Savants et ignorants : une histoire de la vulgarisation des sciences. Paris, Seuil, 1991. 15,3 x 24, 296 p., index (« Science ouverte $"$ ).

Délaissant toute véritable problématique historique ou philosophique, ce panorama n'a d'autre ambition que de proposer une agréable promenade documentaire à travers trois siècles de vulgarisation scientifique en France. Il satisfera davantage l'amateur curieux que le chercheur.

Jean-François BaILLoN.

Elisabeth CrawFord, La Fondation des prix Nobel scientifiques, 1901-1915. Trad. de l'anglais par Nicole Dhombres. Paris, Belin, 1988. 13,5 x 21,5, 239 p., annexes, index (" Regards sur la science ").

Depuis 1974, les archives des institutions responsables de l'attribution des prix Nobel sont accessibles aux chercheurs pour tous les documents qui remontent à cinquante ans ou plus. Ceci a permis aux historiens et aux sociologues des sciences de retracer les débats et les procédures qui ont devancé le choix des lauréats qui, depuis 1901, ont reçu cette récompense prestigieuse.

Elisabeth Crawford était parmi les premiers à exploiter les archives suédoises concernant le prix Nobel. La présente étude, parue d'abord en anglais en 1984, est essentiellement la reconstitution des quinze premières années des prix de chimie et de physique. Cette limitation dans le temps est justifiée par l'histoire, car le livre couvre ainsi toute la période avant la Première Guerre mondiale, laquelle devait provoquer une interruption dans l'octroi des prix. 
Dans le premier chapitre, l'auteur fait le tour d'horizon des prix scientifiques et des distinctions honorifiques antérieures au prix Nobel, pour montrer dans quelle mesure l'industriel suédois et ses exécuteurs testamentaires se sont inspirés du système international de récompenses existant à l'époque. Le deuxième chapitre est consacré à la situation de la science en Suède au début du siècle, et notamment aux institutions scientifiques (Académie, universités, etc.) de ce pays pour qui l'institution du prix Nobel deviendra très vite une affaire d'intérêt national. Dans le troisième chapitre, E. Crawford décrit l'affaire compliquée de la succession Nobel. Il a fallu plus de trois ans aux exécuteurs testamentaires pour résoudre tous les problèmes juridiques, politiques et pratiques qui se sont posés après la mort de Nobel, survenue à San Remo en 1896. Aidé par le gouvernement suédois, ils ont transformé les idées vagues de Nobel en des statuts et des règlements praticables, en dépit des objections de la famille du défunt et des hésitations des futurs responsables de l'attribution des prix. Les statuts définitifs ont finalement été promulgués en juin 1900.

Après cette première partie, que l'auteur considère comme la préhistoire de l'institution des prix Nobel, elle analyse dans les chapitres Iv à vr les modalités de la sélection des lauréats de chimie et de physique de 1901 à 1915. La gamme des facteurs dont dépendaient les propositions faites par les présentateurs suédois et étrangers, s'étendait d'arguments purement scientifiques jusqu'à des considérations d'ordre nationaliste, voire chauvin. Si des candidats comme Planck, Einstein et Nernst n'étaient pas retenus au temps de leurs grandes découvertes (c'est-à-dire avant 1915), c'était à cause d'une définition étroite de la physique, réduite essentiellement à la physique expérimentale. Cette tendance expérimentaliste dominait parmi les présentateurs aussi bien qu'au comité Nobel de physique, et comme il y avait autour de 1900 de nombreuses découvertes de phénomènes obtenues par la voie expérimentale, on était plus facilement enclin à décerner le prix à des savants comme Röntgen, Becquerel, Zeeman et les Curie, dont les découvertes avaient souvent l'avantage supplémentaire de correspondre encore à une autre clause des statuts Nobel : elles avaient rendu des services à l'humanité. Ces considérations d'ordre utilitaire ou humanitaire ne jouèrent pas seulement un rôle dans le cas du premier lauréat de physique (Röntgen), mais aussi dans le contexte des prix décernés dans le domaine de la radioactivité, puisqu'à l'époque où Becquerel et les Curie ont reçu le prix, on venait de découvrir l'utilité thérapeutique du radium contre le cancer. Pour soutenir la candidature de Planck, Arrhenius souligna même, dans un rapport de 1908 , l'utilité pratique de sa théorie du rayonnement pour les techniques d'éclairage. En vertu de la clause des «services rendus à l'humanité ", le comité de physique honora le développement de la TSF en octroyant le prix de 1909 à Marconi et à Braun, mais il se refusa à sanctionner l'invention de l'aviation en raison des risques de mort encourus.

Au chapitre IV, dans un paragraphe intitulé « Nationalisme et internationalisme ", l'auteur examine si le système de présentation a fonctionné dans un esprit international. Pour montrer dans quelle mesure les préférences des présentateurs allaient à leurs compatriotes, elle définit un « indice de chauvinisme " par lequel elle compare la proportion des présentations nationales avec celles provenant de présentateurs d'autres pays. Son analyse révèle que la tendance « nationaliste " était assez répandue chez les Français et les Anglais, où $75 \%$ des présentations en 
physique allaient à des compatriotes, tandis que les Allemands étaient plus réservés à cet égard. En revanche, à la suite des liens anciens et des relations scientifiques privilégiées unissant la Suède et l'Allemagne, il y avait entre ces deux pays ce que Crawford appelle "un axe germano-suédois", au moins en ce qui concerne la physique. Dans cette discipline, $48 \%$ des présentations allemandes reçues de l'étranger provinrent de présentateurs suédois, et les présentateurs allemands accordèrent à leur tour une proportion élevée de votes aux candidats suédois. En chimie, ce furent aussi les présentateurs suédois qui donnèrent proportionnellement le plus de votes aux Allemands, et bien qu'il n'y eût ici pas de réciprocité, la conclusion s'impose que l'Allemagne et la Suède occupèrent des positions clés dans le système.

Le dernier chapitre est intitulé « Les prix, le public et la communautê scientifique ". Il y est d'abord question de l'intérêt que la grande presse a témoigné à l'institution Nobel, et nous apprenons comment, dans le climat de nationalisme et de compétition entre les États qui régnait à cette époque, les prix Nobel furent de plus en plus perçus dans une perspective nationaliste. Dans beaucoup de journaux, on les présentait comme un concours entre les nations, comparable aux Jeux olympiques, et quand un journal allemand commença à dresser des statistiques indiquant le nombre de prix gagnés par chaque pays, ce genre de calcul devint un élément permanent de la publicité pour les prix Nobel. Au début de la guerre, ces statistiques faisaient même partie de la campagne de propagande et de haine entre les intellectuels des pays belligérants, et Wilhelm Ostwald, prix Nobel 1909, s'en servit pour prouver la supériorité de l'Allemagne dans le domaine des sciences qui, selon lui, était due au talent d'organisation propre à la race germanique.

Nombreuses étaient les répercussions des prix Nobel sur la science. Retenons seulement l'aspect financier : souvent, les lauréats utilisaient l'argent du prix pour financer leurs propres travaux ou ceux de leurs laboratoires. Surtout en France et en Angleterre, les prix furent généralement considérés comme des subventions à la recherche, et utilisés dans cet esprit. En plus, l'octroi du prix Nobel a souvent eu un effet bénéfique de propagande. Impressionnés par le prestige que cette récompense entraînait non seulement pour le lauréat, mais aussi pour son pays, les gouvernements étaient souvent prêts à accroître des fonds ou même à créer une chaire (comme dans le cas de Pierre Curie) pour des chercheurs qui avaient travaillé dans des conditions plus ou moins restreintes avant d'être honorés par l'Académie suédoise. Ainsi, grâce au prix Nobel reçu en 1912, Paul Sabatier obtint de nouveaux fonds de l'État pour développer l'Institut de chimie à Toulouse.

Par l'importance des informations qu'il contient, et par la perspicacité de l'analyse des faits tirés de documents qui avaient été pendant longtemps inaccessibles, cet ouvrage mérite de servir de modèle aux futures études sur l'histoire des prix Nobel. On ne peut que souhaiter un travail analogue sur l'histoire des deux autres prix Nobel, celui de la paix et celui de littérature. 